\title{
Hungary's academy fights to build a new role
}

Budapest. A new law redefining the responsibilities of the Hungarian Academy of Sciences as it steers basic research into the post-communist era is still awaiting approval by the parliament, nearly three years after it was introduced.

The bill would give legal backing to the academy's status as a politically independent learned society with a more democratic structure than in the past, and with control over its 39 research institutes. The academy wants this status confirmed as soon as possible to help it negotiate for more funds; its budget has been cut so drastically in recent years that research is almost at a standstill.

But politicians remain divided on the academy's future, partly because many want its power to be reduced, and partly because basic science is not a priority in Hungary's troubled economy. As a result, it now seems unlikely that the bill will be accepted before elections due in May.

The academy was founded as a learned society in 1825 . In the 1920 s and 1930 s, it set up the country's first independent research institutes. But extensive reorganization took place along the lines of the Soviet Academy of Sciences after the communists came to power in 1949 .

At the time, 122 members of the academy were expelled, its political autonomy was abolished — the academy acted as a ministry of science, with control over the allocation of public funds for basic research - and an extensive network of research institutes was established.

Since the election of a postcommunist government in 1990 , the academy has not been represented in the government, and its grant-giving sec-

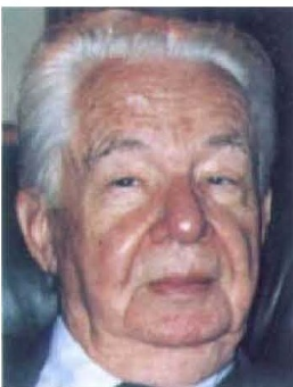

Kosáry: healing old wounds. tion, the Hungarian Science Research Fund (OTKA) has been made independent.

The academy has been quietly introducing its own democratic reforms. For example, it is creating two different levels of scientific board, which include scientists from universities and industry, but exclude institute directors, to decide how money should be divided between its institutes. But political problems remain.

During the four decades of communist rule, for example, the academy provided a research environment that was much richer and freer than that of the universities. It also offered shelter for scientists considered 'politically unfit' for university teaching posts.

Despite this, it now finds that it is having to defend itself against charges that it is perpetuating the influence of communism, despite the election of the anti-communist Domokos Kosáry as president.

Kosáry, a well-known historian who spent four years in jail as a dissident, immediately proclaimed that there would be no 'witch-hunt' against former communists in the academy. But this angered the more zealous reformers in parliament.

He also immediately rehabilitated all of the academy members expelled by the communists in the early $1950 \mathrm{~s}$ apart from one who was judged to have actively helped the

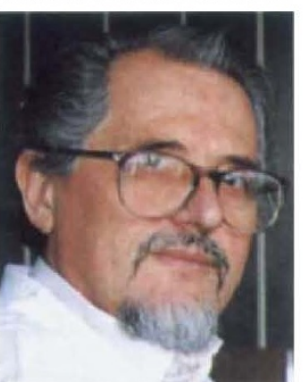

Venetianer: pleased with reforms. fascists during the Second World War.

But this move has also backfired. Two weeks ago a small far-right party, the Foundation of Victims of Communism, rekindled arguments about whether communists still hold power in the academy by claiming that this exception was made because of the scientist's anti-Stalinist politics. The academy vigorously denied the allegation, but in doing so displayed its hypersensitivity to charges of communist sympathies.

Controversy over the academy bill is also being fuelled by Hungary's economic difficulties. Industrial output has been falling steadily since 1989 , and many feel that the country cannot afford the academy's demand to run its research institutes along the lines of Germany's Max Planck Society, where the state foots the bill but has no influence over the direction of research.

Many politicians favour spending any money available on short-term applied research to help Hungary out of its current crisis. Others believe that the research institutes should be handed over to universities.

But scientists in the research institutes wish to remain under the academy's umbrella, says Pál Venetianer, director of the academy's Biological Research Centre in Szeged, south Hungary. They have welcomed the academy's internal reforms, and believe it is now well placed to protect their interests.

The academy is working hard to protect the future of its institutes. But this means negotiating realistic funding, which in turn requires an accepted legal status. "The finance minister does not take us seriously at the moment," says László Keviczky, the academy's secretary general.

The academy's annual budget has fallen sharply, from 5.15 billion Hungarian forint in 1992 to Ft4.86 million (US\$49 million) in 1994, at a time when inflation has been running at between 20 and 30 per cent. "We barely have enough money to cover running costs of our institutes," says Keviczky.

Project money distributed by OTKA has also fallen dramatically; this year for example saw a cut of more than 20 per cent, from Ft2.44 billion to Ft1.92 billion. The academy would like to be able once again to provide project money of its own, says Kosáry, something he will fight for once the academy law is passed.

Between 1990 and 1992, the academy organized international evaluations of its institutes. A common criticism was that institutes were overstaffed yet individual research groups were too small. Staff numbers have fallen by nearly a third, from 7,580 in 1990 to 5,440 now. But this has mostly been the result of scientists leaving the country or going into industry, and by the retirement of many ageing staff.

The main problem now facing the academy is how to keep the remaining staff during the current period of uncertainty and economic difficulties. The average wage of a scientist at group leader level is only US $\$ 300$ a month, a quarter of the equivalent salary in industry. A postdoc earns between US $\$ 180$ and $\$ 200$, a research director, US $\$ 400$. Even the 250 academy members have seen their previous privileged salaries reduced to US\$850 a month.

Low wages and scarce research funds are taking their toll of scientists, many of whom have spent long periods working in the West and are frustrated by the near-impossibility of their situation at home. "There has never been more pressure on us," says Pál Ormos, a 40-year-old director of research at the Biological Research Centre in Szeged. $\mathrm{He}$ is, however, determined to ride out the storm.

Alison Abbott

\section{Howard Hughes opens up awards selection}

Washington. Forty-four researchers -17 at the assistant professor level - are the winners of a nationwide competition run by the Howard Hughes Medical Institute (HHMI) aimed at searching out the best and the brightest that biomedical research in the United States has to offer.

The "competition", made possible by an HHMI endowment that increased by US $\$ 780$ million during 1993, provided the institute with an opportunity to open up the selection and appointment process beyond the 53 universities and medical centres that have HHMI investigators. Indeed, ten of the new appointments fall into this category.

"The best way to make a large number of appointments is to solicit nominations broadly and have them all reviewed together," says Purnell W. Choppin, president of HHMI. 